\title{
First record of a tear-drinking stingless bee Lisotrigona cacciae (Nurse) (Hymenoptera: Apidae: Meliponini), from the central hills of Sri Lanka
}

\author{
W.A.I.P. Karunaratne ${ }^{1 *}$, J.P. Edirisinghe ${ }^{1}$ and Michael S. Engel ${ }^{2}$ \\ ${ }^{I}$ Department of Zoology, Faculty of Science, University of Peradeniya, Peradeniya. \\ ${ }^{2}$ Division of Entomology, Natural History Museum and Department of Ecology and Evolutionary Biology, University of Kansas, Lawrence, Kansas \\ 66045-4415, USA.
}

\begin{abstract}
Presently, a single species of stingless bee, Tetragonula iridipennis (Smith)(Hymenoptera:Apidae:Apinae: Meliponini) is known to occur throughout Sri Lanka. Recently, during field studies in central Sri Lanka, a second genus and a species has been recorded for the island. The minute species, Lisotrigona cacciae (Nurse), is of a rare genus previously known only from northern Borneo and scattered locations in mainland southern Asia. More importantly, this species belongs to a peculiar group of tiny bees that are lachryphagous, feeding on tears secreted from the eyes of mammals, birds, and some reptiles. This is a highly specialised behaviour and biology that remains poorly understood, and generally differs from the well known pollen- and nectar-feeding ethology of most other bees. The discovery of this species provides opportunities for future research into the biology of these bees, and elevates the total bee fauna of Sri Lanka to 149 species in 39 genera.
\end{abstract}

Keywords: Knuckles Forest Reserve, Lisotrigona cacciae, new record, Sri Lanka, stingless bees.

\section{INTRODUCTION}

The stingless bees comprise a pantropical lineage of approximately 500 highly eusocial bees, classified as the tribe Meliponini (Michener, 2007a). Although distributed in both hemispheres, the meliponines are most diverse in the New World (Michener, 2007a; 2013), and much less so in the Oriental Region, presumably the result of long-term, historical competition with honey bees since the Oligocene epoch (Engel, 2001). These bees live in perennial colonies and are critical pollinators, and various species are managed for their honey or pollination services in a similar fashion as are honey bees (Wille \&
Michener, 1973; Michener, 2007a; 2013). Most species collect pollen, nectar, honeydew and plant resins and use these materials either as food, or for nest construction (Michener, 2007a; 2013). However, a few rare species are specialised to collect protein-rich tears from the eyes of varied mammals, birds, and selected reptiles (known as lachryphagy), representing a wholly unique biology among bees (Bänziger \& Bänziger, 2010). In particular, the minute species of the genus Lisotrigona Moure are well documented for their tear-drinking behaviour in southern Asia (Bänziger et al., 2009). Species of Lisotrigona are uncommonly encountered, although three species are found across a wide swath of Southeast Asia; Lisotrigona carpenteri Engel known from Vietnam and Cambodia; L. furva Engel found widespread in Thailand; and L. cacciae (Nurse) in various southern Asian countries as well as in Borneo (Engel, 2000; Michener 2007b; Lee et al., 2016). Samples from Kerala, India, proposed as a separate species are almost assuredly a synonym for L. furva, and represents an extension of that species into southern India (Jobiraj \& Narendran, 2004).

Hitherto, only a single stingless bee species, Tetragonula iridipennis (Smith), has been formally recorded from Sri Lanka (Karunaratne et al., 2005). The recent discovery of individuals of a tear-drinking species of Lisotrigona in central Sri Lanka, therefore, not only expands the range of the genus, but represents a significant addition to our native stingless bee fauna and reveals the presence of lachryphagous meliponines on the island. 


\section{METHODOLOGY}

During a survey of bees conducted in 2001 at selected localities across the island, several visits were made to the Pallegama area (Latitude 7.545472, Longitude 80.821104) of the Knuckles Forest Reserve in the central hills of Sri Lanka. On one collecting excursion (30 January 2002), several tiny insects with an unusual behaviour were observed. These insects were flying around the faces of the collectors for several hours to the annoyance of the researchers while sampling for bees in an abandoned land, otherwise covered with flowering herbs. A few individuals were captured with a hand net for close observation and were found to be minute stingless bees previously unknown from Sri Lanka. These bees were never observed to forage (for pollen or nectar) in the weed patch, and their nest sites could not be located at that time. Three individuals were sampled and mounted. Permits from the Department of Wildlife Conservation, Sri Lanka, allowed the material to be sent to the third author for identification. The material was compared against previously identified specimens in the reference collection of the University of Kansas Natural History Museum by both the third author and the late Prof. C.D. Michener, both of whom identified the species as L. cacciae. Two specimens were deposited in the bee collection of the Invertebrate Systematics and Diversity Facility, Department of Zoology, University of Peradeniya, Sri Lanka.

\section{SYSTEMATIC NOTE}

\section{Lisotrigona cacciae (Nurse)}

\section{Diagnosis}

The species of Lisotrigona are exceedingly similar, and while $L$. carpenteri can be distinguished rather easily by its more extensive yellow markings and slightly larger body size (Engel, 2000), L. furva and L. cacciae are more difficult to separate, particularly where the species are sympatric. Nonetheless, workers of $L$. cacciae can be consistently distinguished from those of L. furva on the basis of head width, the former ranging from $1.08-1.18 \mathrm{~mm}$, while in the latter species the known range is $1.25-1.35 \mathrm{~mm}$ (Michener, 2007b). There are minor colour differences between the two species, but in each there are variations that come close or even overlap the pattern observed in either taxon. Thus, while colour may be helpful, in isolation of morphometrics it cannot always separate the two species. Individuals of L. cacciae tend to have more frequent brown to dark brown colouration, or areas tinged with yellowish brown,

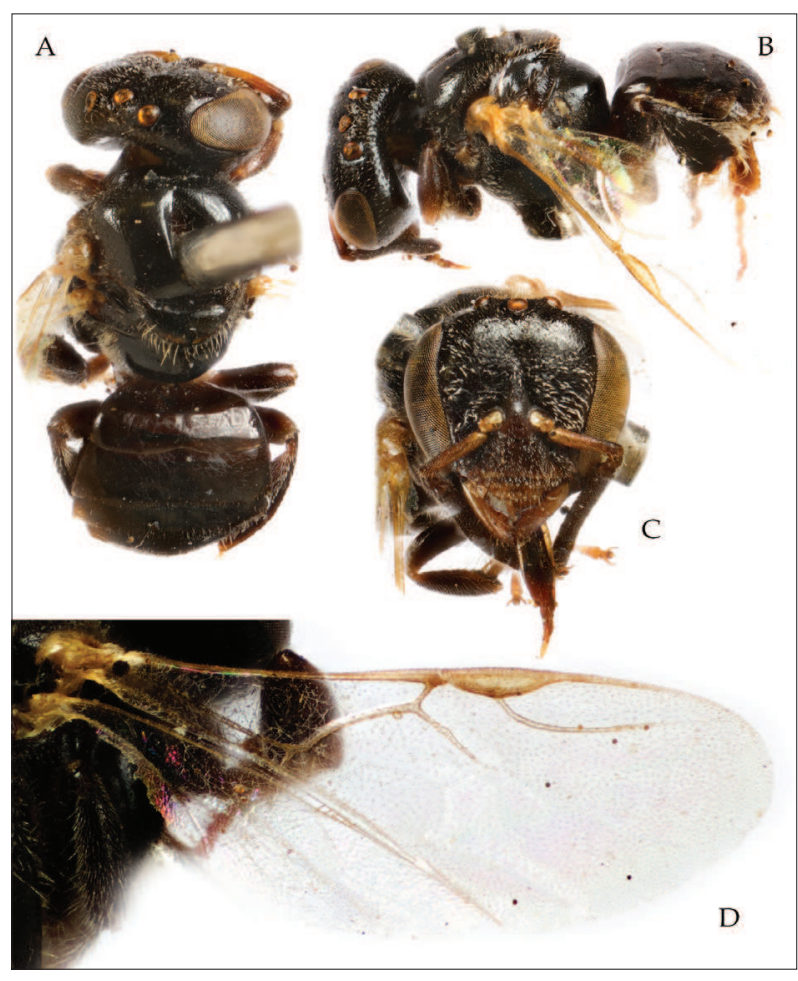

Figure 1: Microphotographs of a worker of the tear-drinking stingless bee Lisotrigona cacciae (Nurse), captured in the Knuckles Forest Reserve. (A) dorsal habitus; (B) lateral habitus; (C) facial view; (D) detail of wing venation

while in L. furva these same areas are often coal black (Engel, 2000; Michener, 2007b). There is also a tendency for the hypoepimeron to lack pubescence in L. cacciae, while in the same area in L. furva, setae are distinctly present (Engel, 2000).

\section{Distribution}

Lisotrigona cacciae is presently recorded from central India (Madhya Pradesh), Laos, Cambodia, southern Vietnam, northern and central Thailand, and northern Borneo (Engel, 2000; Michener, 2007b).

\section{CONCLUSION}

Southeast Asia harbours two genera of minute stingless bees, Lisotrigona and the monotypic Pariotrigona Moure (Michener, 2001; 2007a; b), and both of these comprise the known lachryphagous species of the region (Bänziger et al., 2009; 2011; Bänziger \& Bänziger, 2010). Pariotrigona pendleburyi (Schwarz) is known from western Malaysia, Brunei, Sabah, northern Sumatra, and southern Thailand (Michener, 2001), and 
is remarkable for its calcicolous nesting preferences (Bänziger et al., 2011). Nests have been documented for only $P$. pendleburyi and $L$. carpenter (Chinh et al., 2005; Bänziger et al., 2011), and there remains much fundamental knowledge to uncover about these lachryphagous species. The discovery of populations of L. cacciae in Sri Lanka provides a new opportunity to study the location of nests and elaborate the behaviour and biology of these enigmatic and minute bees. Furthermore, owing to the dearth of available material, a complete understanding of the variation and species circumscription for these taxa is needed (Engel, 2011; Gonzalez et al., 2013), ideally based on a combination of geometric, morphometric and molecular methods. Such work must await extensive sampling of these bees from across their ranges to fill in the broad gaps in distribution, ideally including all of the social castes, as males are known only in L. furva and P. pendleburyi (Michener, 2001; 2007b). For the time being, however, the finding of $L$. cacciae in the Knuckles Forest Reserve adds an important species to the list of known native bees in Sri Lanka. Including this lachryphagous meliponine brings the total bee fauna for the country to 149 species in 39 genera (Karunaratne et al., 2005). This discovery highlights the need for continued biotic surveys across Sri Lanka including the remarkable diversity of the island's bee fauna.

\section{Acknowledgement}

The authors are grateful to the late Prof. C.D. Michener for his expert assistance and advice, and for his general support. The National Science Foundation (NSF) of Sri Lanka is acknowledged for providing funds (Grant No: RG/2001/B/2) for the survey of wild bees in Sri Lanka, while the work of Michael S. Engel had been generally supported by the U.S. National Science Foundation grant DEB-1057366. We are also thankful to the Department of Wildlife Conservation and the Forest Department, Sri Lanka, for facilitating our collaborative work.

\section{REFERENCES}

1. Bänziger H., Boongird S., Sukumalanand P. \& Bänziger S. (2009). Bees (Hymenoptera: Apidae) that drink human tears. Journal of the Kansas Entomological Society 82(2): $135-150$.

DOI: https://doi.org/10.2317/JKES0811.17.1

2. Bänziger H., Pumikong S. \& Srimuang K-O. (2011). The remarkable nest entrance of tear drinking Pariotrigona klossi and other stingless bees nesting in limestone cavities (Hymenoptera: Apidae). Journal of the Kansas Entomological Society 84(1): 22 - 35.

DOI: https://doi.org/10.2317/JKES100607.1
3. Bänziger H. \& Bänziger S. (2010). Mammals, birds and reptiles as hosts of Lisotrigona bees, the tear drinkers with the broadest host range (Hymenoptera, Apidae). Mitteilungen der Schweizerischen Entomologischen Gesellschaft 83(3-4): $271-282$.

4. Chinh T.X., Sommeijer M.J., Boot W.J. \& Michener C.D. (2005). Nest and colony characteristics of three stingless bee species in Vietnam with the first description of the nest of Lisotrigona carpenteri (Hymenoptera: Apidae: Meliponini). Journal of the Kansas Entomological Society 78(4): $363-372$.

DOI: https://doi.org/10.2317/0409.14.1

5. Engel M.S. (2000). A review of the Indo-Malayan meliponine genus Lisotrigona, with two new species (Hymenoptera: Apidae). Oriental Insects 34: 229 - 237. DOI: https://doi.org/10.1080/00305316.2000.10417261

6. Engel M.S. (2001). A monograph of the Baltic amber bees and evolution of the Apoidea (Hymenoptera). Bulletin of the American Museum of Natural History 259: 1 - 192.

7. Engel M.S. (2011). Systematic melittology: where to from here? Systematic Entomology 36(1): 2 - 15.

DOI: https://doi.org/10.1111/j.1365-3113.2010.00544.x

8. Gonzalez V.H., Griswold T. \& Engel M.S. (2013). Obtaining a better taxonomic understanding of native bees: where do we start? Systematic Entomology 38(4): 645 - 653.

DOI: https://doi.org/10.1111/syen.12029

9. Jobiraj T. \& Narendran T.C. (2004). A revised key to the world species of Lisotrigona Moure (Hymenoptera: Apoidea: Apidae) with description of a new species from India. Entomon 29(1): $39-43$.

10. Karunaratne W.A.I.P., Edirisinghe J.P. \& Pauly A. (2005). An updated checklist of bees of Sri Lanka with new records. Publication No. 23. MAB Handbook and Occasional Paper Series. National Science Foundation, 47/5, Maitland Place, Colombo 07.

11. Lee S., Duwal R.K. \& Lee W. (2016). Diversity of stingless bees (Hymenoptera, Apidae, Meliponini) from Cambodia and Laos. Journal of Asia-Pacific Entomology 19(4): $947-961$.

DOI: https://doi.org/10.1016/j.aspen.2016.04.018

12. Michener C.D. (2001). Comments on minute Meliponini and the male of the genus Pariotrigona (Hymenoptera: Apidae). Journal of the Kansas Entomological Society 74(4): $231-236$.

13. Michener C.D. (2007a). The Bees of the World, $2^{\text {nd }}$ Edition, pp. 953. Johns Hopkins University Press, Baltimore, Maryland, USA.

14. Michener C.D. (2007b). Lisotrigona in Thailand, and the male of the genus (Hymenoptera: Apidae: Meliponini). Journal of the Kansas Entomological Society 80(2): $130-135$.

15. Michener C.D. (2013). The Meliponini. Pot-Honey: A Legacy of Stingless Bees (eds. P. Vit, S.R.M. Pedro \& D.W. Roubik), pp. 3 - 17. Springer Verlag, Berlin, Germany. DOI: https://doi.org/10.1007/978-1-4614-4960-7_1

16. Wille A. \& Michener C.D. (1973). The nest architecture of stingless bees with special reference to those of Costa Rica (Hymenoptera: Apidae). Revista de Biología Tropical 21(Suplemento I ): 1 - 278. 